\title{
Development of Islamic Teachings through the Translation of the Quran in Various National Languages
}

DOI: https://doi.org/10.47175/rissj.v3i1.377

\section{| Moh. Ali Abdul Shomad Very Eko Atmojo ${ }^{1}$ | Elfi Mu'awanah ${ }^{2 *}$ | | Ali Rohmad ${ }^{3}$ | Munardji $^{4}$ | Umy Zahrok ${ }^{5}$ | Hibbi Farihin ${ }^{6}$ | | Germino Wahyu Broto ${ }^{7}$ | Rifa Hidayah ${ }^{8}$ |}

1,2,3,4,5,6,7 UIN Syayyid Ali

Rahmatullah Tulungagung, Indonesia

${ }^{8}$ UIN Maulana Malik Ibrahim Malang

${ }^{1}$ alishomad74@gmail.com,

2*elfi_muawanah@yahoo.co.id,

${ }^{3}$ damhorila@yahoo.co.id,

${ }^{4}$ munardji@iain-tulungagung.ac.id,

5umyzahrok@gmail.com,

6hibbifarihin@gmail.com,

7 massino.debro@gmail.com,

8ifa_hidayah@psi.uin-malang.ac.id

\begin{abstract}
From the research on the translation of the Quran, in various countries in the center of places of worship, it is known that there are already translations so that it is hoped that it will increase interest in reading and understanding the contents of the Quran. The translation of the Quran is an interpretation of the holy book of Islam in a language other than Arabic. The Quran has been translated into most languages by the translator. The translation of the Quran has always been a troubled and difficult issue in Islamic theology. Because Muslims respect the Quran as a miracle and incomparable (i'jaz al-Quran), they argue that the Quranic text cannot be reproduced in other languages or other forms. The translation of the Quran in its history undergoes a lengthy process, for example from the question of authority or the legitimacy of the translator, the law of translation, coupled with the presence of the translation made by the Orientalists making many differences among the scholars in addressing the translation of the Quran. KEYWORDS

translation; psycologycal impact; ijtihad
\end{abstract}

\section{INTRODUCTION}

Quran translation research in several countries is very necessary to understand the contents of Quran reading for Muslims. The center of Islamic teachings in it can serve as guardians of teachings, as daily readings to protect oneself from the weakness of one's faith. Reading the Quran (QS Al Fathur verse: 39-40) is rewarding for the reader, and reading it is worship, especially learning the Quran and practicing it in everyday life. In order for language differences in countries where the Quran was not revealed, it is necessary to understand the Quran in the language of a country outside of Arabic. Terms to translate the Quran include : 1. The translation of the Quran should not replaced by the Quran, so until someone feels no need for the Quran, this is not allowed. So, it should be written Al-Quran with Arabic / Arabic language, meanwhile it is written translated maknawiyyah of the Quran, as explanation of its content. 2. The translator should know madlulat lafadz (the meaning is indicated by lafadz indication) in two languages, the source language and the target language, and the content indicated by the context of the sentence. 3 . The translator must know the meaning of lafadz-lafadz syar'i in the Quran. 4. Translators should be credible (trustworthy), ie Muslims and Shalih (both in science and charity).

The law of translating the Quran with maknawiyyah translation is originally permissible because there is no prohibition, even sometimes, the law is obligatory, that is when its existence as a means to teach / convey the Quran and Islam to people who do not understand 
the language Arabic because teaching / delivering the Quran is mandatory, with the following rules:ما لا يتم الواجب إلا به فهو واجب

"A matter which an obligation cannot be done except with it, then the law of the case is also obligatory". "A thing that cannot be done by an obligation except with it, then the law is also obligatory". Translating makes it very necessary for the contents of the Quran to be conveyed to followers of the Islamic religion in various countries, while reading the Quran anywhere remains the same even though it is read in the language of any country. The term harfiyyah is sometimes allowed when a translator wants to translate a certain word in the Quran into the language of the audience so that he understands the word correctly, but with the notes the translator does not translate the order of sentences altogether, so as to translate the word. Currently in context current research researchers tend to do the translation of the Quran is intended for specific purposes according to the study of researchers in the field of counselling psychology.

To provide therapy required translation of the verses of the Quran, because the researchers predict that the Quran approach to therapy (Goryunova, Krainyukov, 2021) especially if the verses of the Quran is known to strengthen to the counselee who is in need of assistance mental health restoration including in terms of defense of behavior phenomena is experienced by the counselee. This is other the benefit of translation Quran for dicipline of knowledge, besides translation is for understand, spreading Islamic teaching.

\section{RESEARCH METHODS}

The method of translation Quran as qualitative research (Padge, 2004) in this study using the method of hermeneutic circle describes the process of understanding hermeneutical text. It is believed that one's understanding of the text as a whole is fixed (Borg, W.R \& Gall, 1983) by reference to the whole text of which no one else can be distinguished from the other, and hence, it is a circle. However, this circular interpretation character does not emphasize that I have found the text in cultural, historical, and literary context . Hermeneutic circle involved in the interpretation of parts of text and the whole part of the bigger text. The characteristics of the Hermeneutic method are that of the text as the subject of the study (Essay), and follow the steps of the Hermeneutic circle method, traits of openness (Nachiappan, S.,.Andi, H K, Veeran, V.K.P., Ahmad, AI., Fatimah, 2014), Traits of Ignorance in Text (Ontoenigma) including ontopretation of Quran(Gadamer, 1976). The Quran (Siregar, 2021) translation formula is in accordance with a person's language and language where he lives and is taken as a basis for one's guidance for his life.

Therefore, the experiment in this study is done through the history of case studies by identifying the problems experienced by the subject by analyzing all the description of the event experienced, including the cultural dilemma faced by subject's confidence in the facts of European and Indonesia Cultural. Then observation of case studies involving a certain time to visualize the events experienced by the subject, the facts of dilema and the words of the cultural of European and Indonesian and the phenomenon of post-dilema emotional phrase gesture. The historical oral is done in this research by listening and recording all the feelings and words of dilema's subjects and conflict opponents, the impacts and events that accompany the dilema. Then proceed with the analysis together with the subject of decision choices that will be lived and take the appropriate attitude with situational analysis, and the researchers conduct clinical case study provide treatment in accordance with the conflict of choice subjects decisions that the dilema experienced should be resolved and build the mental strength of the subject to accept the risk of dilema of European and Indonesian besides the Japan. 


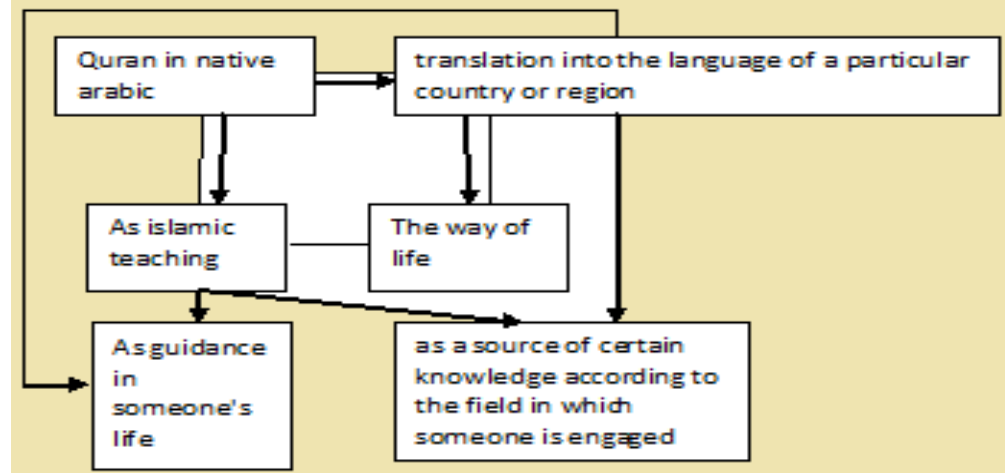

Figure 1. Translation Research Fremework

\section{RESULTS AND DISCUSSION}

Examples of translations of the Quran, each translation always juxtaposed the original Arabic language Quran. In the psychological context of the translation of the Quranic verse or the reading of the prayer after reading the Quran, it is very important to convince the individual to motivate himself and to seek God's help for all the problems he is experiencing. The importance of translation is to assist in the selection of verses that are appropriate to the context and at the same time, it helps to disseminate the content of the Quran to the community in order to be used for the grip of life as Muslims. Without translation it is difficult for a layman to understand the meaning of the Quran.

Taking the Quran and translating to be taken advantage of in certain areas is necessary, to understand more deeply the conditions of the Quranic text and conditions outside the structure of the Quranic language is essential. example of the text of the Quran in the letter Yasin and it motivates the public to read the letter Yasin because it is also supported (Cook, C., Powell A., n.d.) the ability of translators to take the wisdom so disarming motivation reward there is another motivation based on certain reference book there is another fadhilah in reading yasin letter shrunk with a prayer that is promised after reading the letter Yaasin and translation in Java language(M.C. Ricklefs, 1979). This is actually the power of understanding, believing certain content and fadhilah from reading the Quran will encourage the love of Muslims to practice the reading of the letter as well as the request of the reader of the letter yasin in prayer which means it is very strengthening mental person (J., 2017). Of course, the efforts to eliminate sadness (Nachiappan, S.,.Andi, H K, Veeran, V.K.P., Ahmad, AI., Fatimah, 2014) and uneasyy are strongly supported by the translation of the Quran.

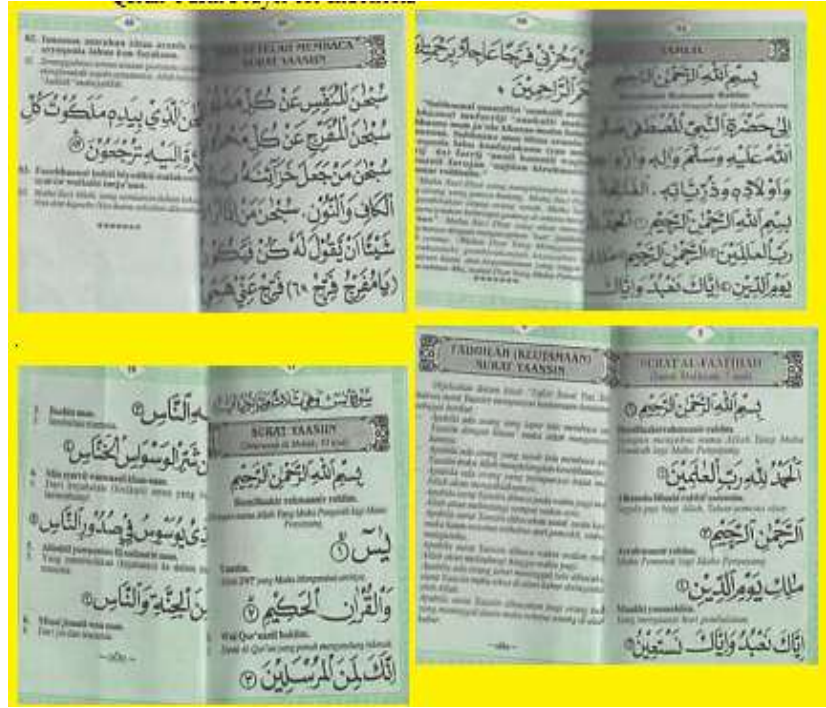

Figure 2. Translation Quran Letter Yasin with Hikmah Quran Reading of Yasin and Quran Yasin Prayer for Indonesia 
Quran translation for the development of motivations for certain disciplines such as counseling psychology

Like such as taking the Quran for conflict counseling (Mu'awanah, 2017), Quran for economic counseling (Muawanah, 2018), Quran for Hajj counseling (Mu'awanah, 2018), the researcher immediately took the Quran as an aspect of translation and science as well as the field of research. In comprehending original Arab Ianguage according to $(K, 2005)$ and translating to represent method of ijtihad related to etimology is very needed in struggling submit Islamic teaching. In consequence someone mujathid claimed to comprehend elementary Ianguage of Holy passing, it means that to pass quickly, hence the existence of translation and understanding is important. Again, it is very needed to overspread Islamic teaching mission. Thereby to certain state is including Indonesia of jihad(K, 2005) through Holy translation. It is important to conduct this research in order to avoid misunderstanding to Holy teaching. But it remains to be needed by understanding Holy sentences which have clear meaning, the clarification does not need the detailed or Holy's interpretation. To translate Holy is representing the way of Allah takes care of Holy so that it remains to spread over in all angle of world.

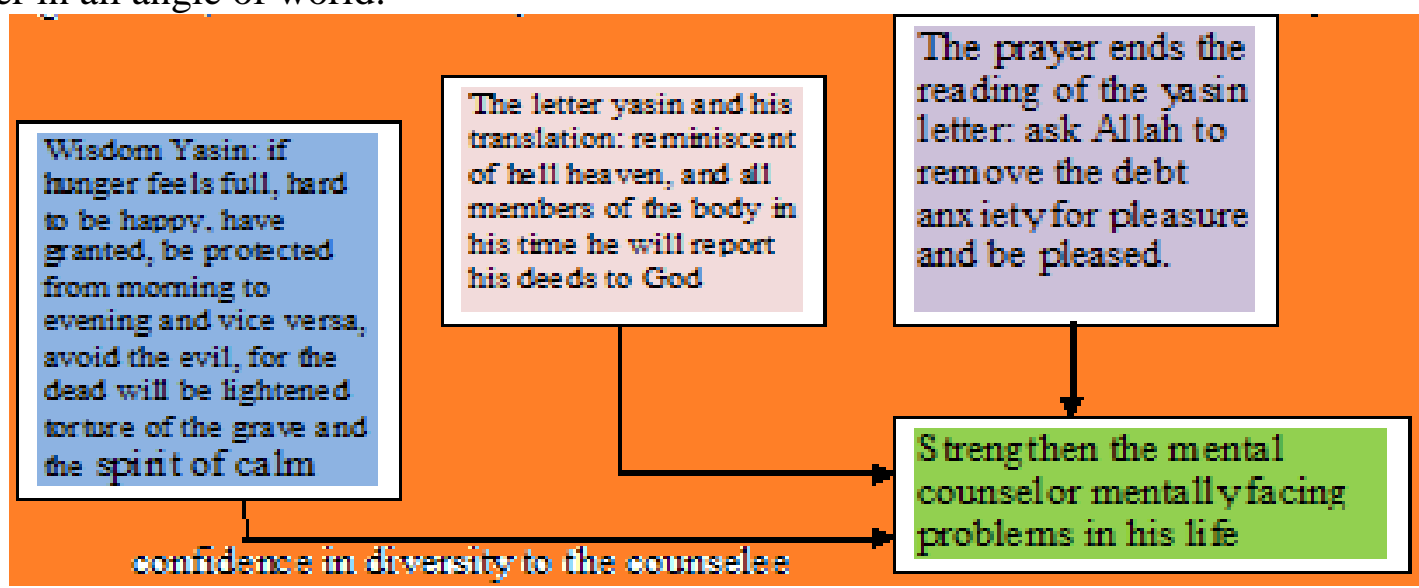

Figure 3. Impact Translation Holy and Letter of Yasin accompanied Hikman and Prayer

The impact of the translation of the Quran along with the wisdom and prayer of reading the Quranic verses is very supportive of mental health (Lubis, 2011) the main Muslims of Indonesia Muslims. A translator translates into influencing the Quranic teaching in everyday life. In this research translation in the context of public health counselling (Sajadi, M., Niazi, M., Khosravi S., Yaghobi, A, Rezaei, M., 2018), the presence of translation is necessary. translation in the language of another country can be seen in some of the following pictures.
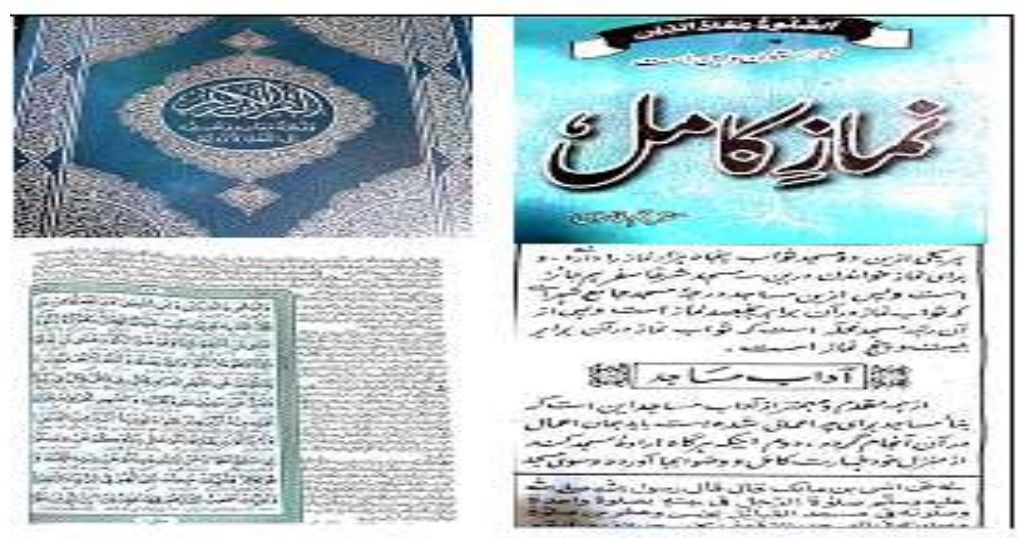
The Quran in various languages was found by researchers at the only Nishihara mosque in Okinawa Japan.
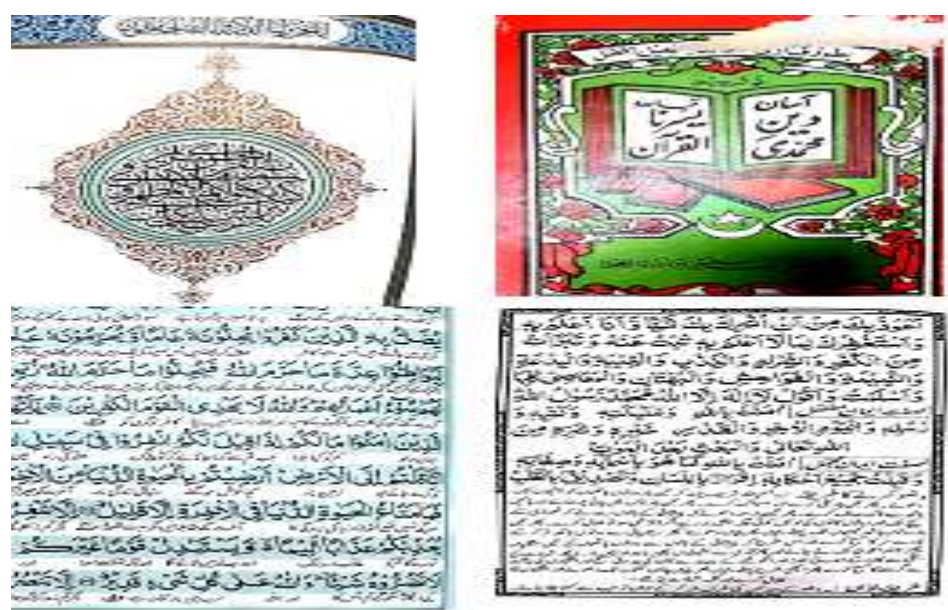

Translation Quran for may of life $=$ islamic teaching

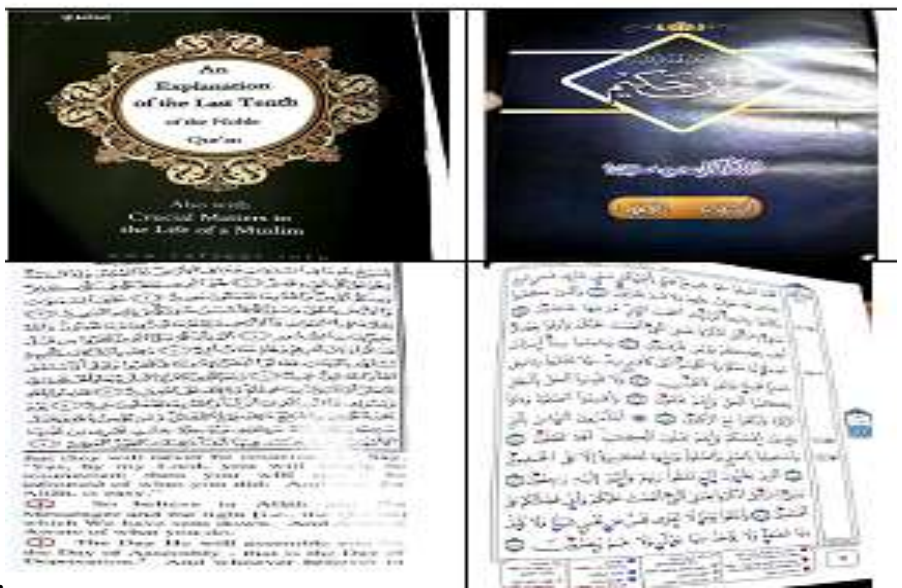

Quran translation for teaching Islamic teaching
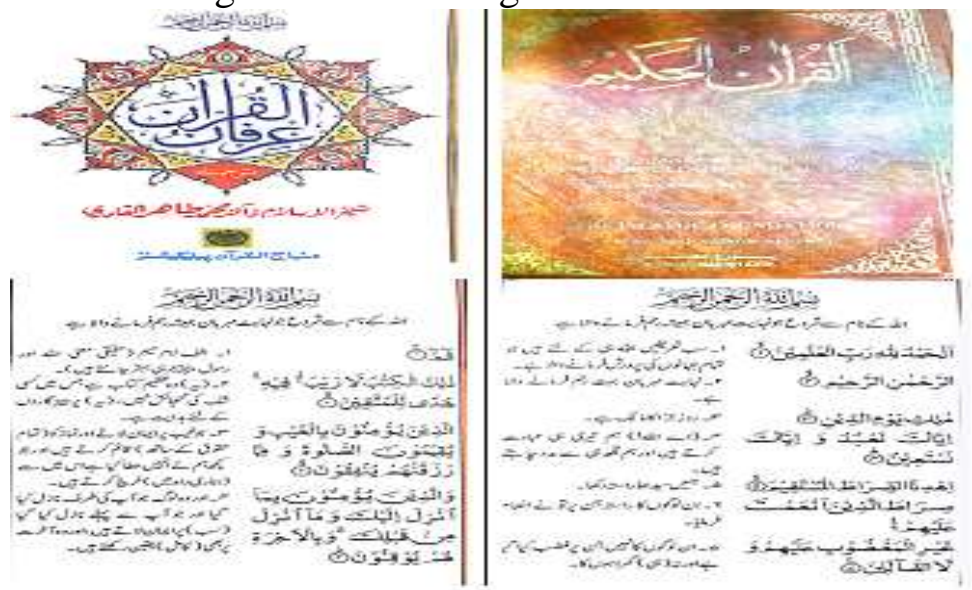

Translation of the Quran in the language of one's territory to be used as an understanding of the teachings of Islam

That the translation of the Quran is indispensable in the language of every Muslim in the World iincluding in the world. That the interests of translation can support the process of contextualizing Quranic verses in the interest of scientific development.To strengthen someone's religion (Alorani O.I, \& ARadaydeh, 2017) of can develop religion teaching of Islam translate Holy all very is needed. beside Holy have a meaning as manual in life, the 
importance of comprehending culture life of society represents matter which needeed to conduct such as he becomes a moslem or he wishes to invite others to be moslem or to fortify x'self of culture which is being expanded in life of society.

\section{CONCLUSION}

When A moslem is experiencing Islam with translation to the region, it means or in English or the other region shall take care of belief in God and religious service practice of wherever and in a condition any(Brink, 2001), they are ready to live with geographical in a condition like any, remain to conduct jihad fi sabilillah.

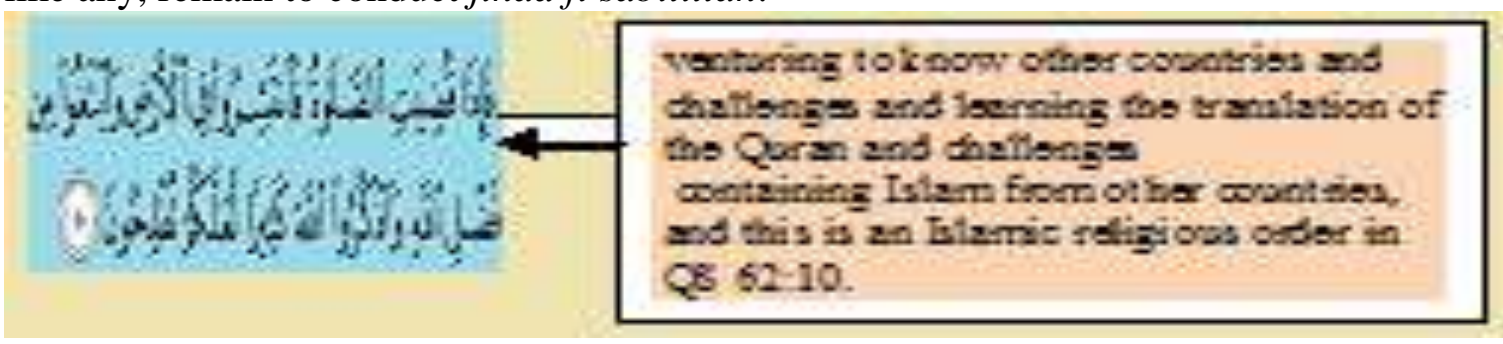

Figure 4. Recommended Wandering

Seeing the moment to moslem jihad such as to fight against free-sex and avoid pornography whereas in Japan, most Japanese people prefer to keep dogs as their pet, eat pork and drink alchohol. Though some people stay in islamic minority in this world, mostly, they could be consistent (Goetzmann, L.,. Goetzmann, L ., Huber L.W.,. Klaghofer, R. Muellhaupt, B.,. Clavien P.A.,. Buddeberg, C\&Scheuer, 2006) to take care of belief in God and they also have to remain their ihsan. Whereas observing the state of Islam in Malaysia for example in Selangor as a moslem, he could face any challenges eventhough he works in Islamic state or country. He could be trapped as worker of non moslem so that it is impossible for him to get a permission to pray or he could leave sholat. Having taubah can be done as soon as possible and try to exit of circle of these bad situations. However, it depends on each individual, could s/he defends his/her iman or faith to God(P.H, 2017) .

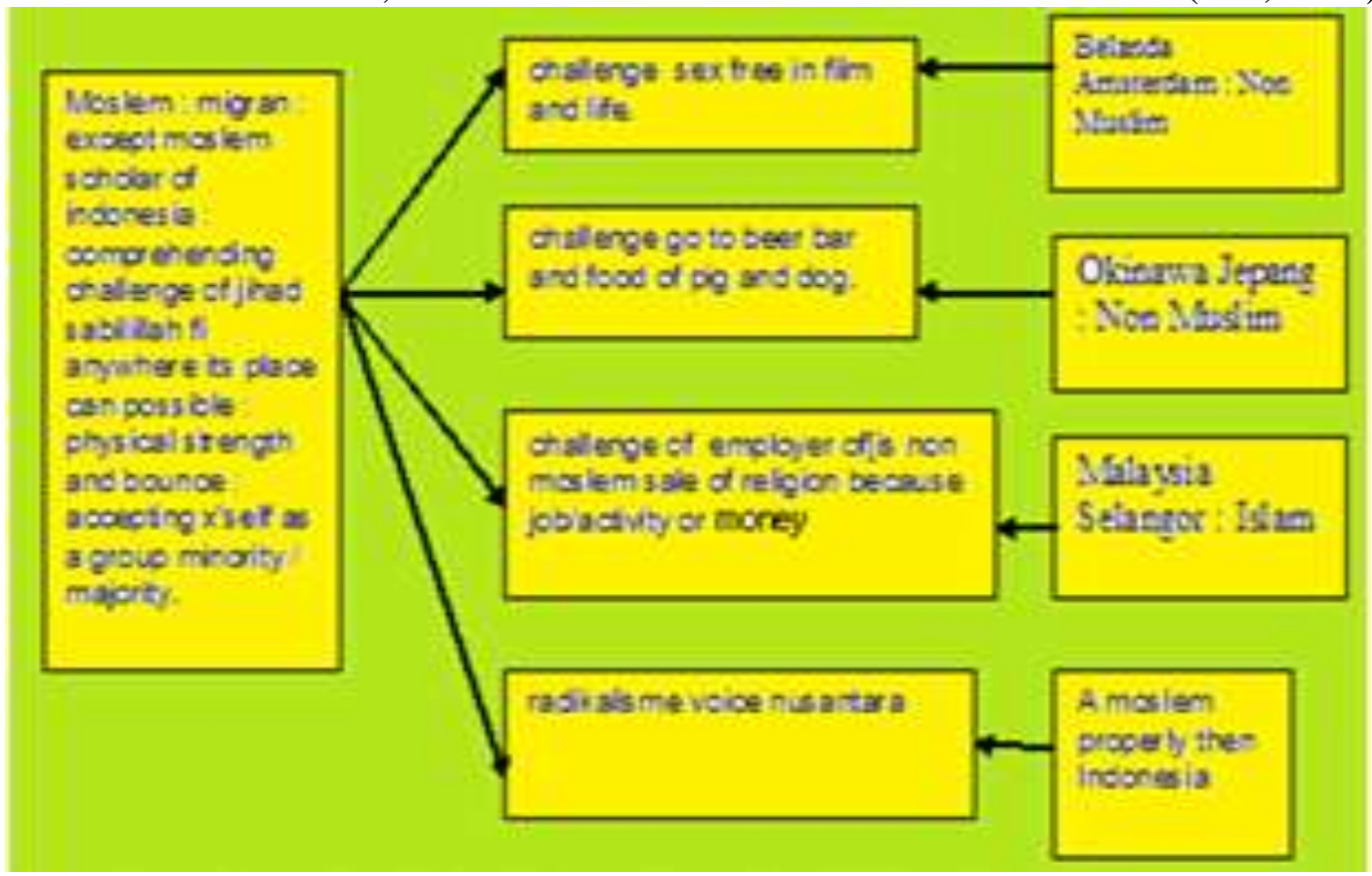

Figure 5. Conclussion for Muslim Migram when dispread islamic teaching 
The command of QS 62:10 can be used as an experience in the importance of translating the Quran in all languages primarily in disseminating the teachings of Islam. besides that a muslim needs to understand the region of the country he is visiting and what challenges he faces in order to carry out the contents of the Koran teachings and even the translation of the Quran. challenges in non-Muslim countries of Muslim countries. in non-Muslim countries there is even a translation of the complete Quran translation in certain country languages like urdu, india, english and others.

Even so it can be formulated by researchers that :

\section{$\mathrm{TQ}=\mathrm{USIT}+\mathrm{FKQ}=2 \operatorname{In} 1$}

note:

$\mathrm{TQ}=$ Translation of the Quran

USIT $=$ Understanding, Spreading Islamic teaching

FKQ $=$ Finding Knowledge bases on Quran

The two advantages of getting someone when they are doing a translation or learning the translation of the Quran in addition to someone being able to understand the teachings of Islam in the Quran can also find knowledge that is built based on the Quran according to the scientific discipline they have. this is what $2 \operatorname{In} 1$ means in this study.

\section{REFERENCES}

Alorani O.I, \& ARadaydeh, R. . (2017). Depression, Aggression And Spiritual Well Being AmongThe University Students In Jordan. European Scientific Journal, 13, 1857 - 7881. https://doi.org/10.19044/esj.2016.v13n2p269

Borg, W.R \& Gall, D. M. (1983). Educational Research An introduction. America: Longman Inc.

Brink, S. K. (2001). Religion and Education in a Changing Indonesia, Kultur,. The Indonesian Journal for Muslim Cultures, 1/2, 9-28.

Cook, C., Powell A., S. A. (n.d.). Spirituality and psychiatry. United Kingdom: The Royal College of Psychiatrists Bell \& Bain Limited, Glasgow.

Gadamer, H. G. (1976). Philosiphical Hermeneutics. (T rans. \& Edited). California: Linge. D. E., University of California Press.

Goetzmann, L.,. Goetzmann, L ., Huber L.W.,. Klaghofer, R. Muellhaupt, B.,. Clavien P.A.,. Buddeberg, C\&Scheuer, E. (2006). Psychosocial well-being and need for counselling during the evaluation procedure. Transplantation Proceedings, 38, 2931-2936. https://doi.org/doi:10.1016/j.transproceed.2006.08.1712931-2936

Goryunova, Krainyukov, Y. V. (2021). Psychosemantic Analysis of Metaphors in Psychological Counseling. Counseling Psychology and Psychotherapy, 20(1), 165-183. https://doi.org/https://doi.org/10.17759/cpp.2021290110

J., G. (2017). Embodiment of the Spirit: A Case Study. Spiritual Psychology and Counseling, 2, 55-72. https://doi.org/http://dx.doi.org/10.12738/spc.2017.1.0015

K, S. (2005). Ijtihad Methode of Ibnu Rusyd. Malang: Kutub Minar.

Lubis, A. . (2011). Islamic Counseling: The Services Of Mental Health And Education For People. Religious Education, 106:5, 494-503. https://doi.org/10.1080/00344087.2011.613347

M.C. Ricklefs. (1979). "Six Centuries of Islamization in Java" in Nehemia Levtzion, Conversion to Islam. New York: Holmes \& Meier. 
Mu'awanah, E. (2017). Cross cultural-spiritual counseling to Adressing personal conflict for facing Individually megacompetition in Globalization ERA Malaysia. International Seminar On Counselling, 267-276. Retrieved from eisbn: 978-967-14139-9-9

Mu'awanah, E. (2018). The Implementation Of Cognitive Behavioral Counselling At Process Of Haji Narrative Analysis (Self Restructuring As Self Spiritual Counselling). International Psychological Applications Conference and Trends, 73-78. Retrieved from http://inpact-psychologyconference.org/wp-content/uploads/2018/05/PsychologicalApplications-and-Trends-2018.pdf.

Muawanah, E. (2018). Counseling Psychology for Majlis Ta'lim Congregation in Improving the Ability to Survive in Conditions of Managemen the Economic Crisis. ISESS, International Symposium on Education and Social Sciences, 178-205. Okinawa Japan: ISBN 978-986-5654-45-0.

Nachiappan, S.,.Andi, H K, Veeran, V.K.P., Ahmad, AI., Fatimah, M. Z. (2014). Analysis of Cognition Integration in Intelligence Quotient (IQ), Emotional Quotient (EQ) and Spiritual Quotient (SQ) in Transforming Cameron Highlands Youths through Hermeneutics Pedagogy. Procedia - Social and Behavioral Sciences, 112, 888 - 897. https://doi.org/10.1016/j.sbspro.2014.01.1246

P.H, K. (2017). Four Inclinations in Human Nature:Evaluated in Light of Al-Ghazzâlî's Concept of the Heart. Spiritual Psychology And Counseling, 2(1), 2458-9675. https://doi.org/10.12738/spc.2017.1.00162017

Padge, K. D. (2004). The Qualitative Research Experience. America: Wadsworth.

Sajadi, M., Niazi, M., Khosravi S., Yaghobi, A, Rezaei, M., K. G. H. (2018). Effect of spiritua 1 counseling on spiritual well-being in Iranian women with cancer: A randomized clinical trial. Complementary Therapies in Clinical Practice, 30, :79-84. https://doi.org/https://doi.org/10.1016/j.ctcp.2017.12.011

Siregar, A. (2021). The Concept of Property and Ownership i n Islam. Randwick International of Social Science $S, \quad 2(4), \quad 341-346$. https://doi.org/https://doi.org/10.47175/rissj.v 2 i 4 . 314 